University of Nebraska - Lincoln

DigitalCommons@University of Nebraska - Lincoln

To Improve the Academy

Professional and Organizational Development Network in Higher Education

1994

Putting Empowerment to Work in the Classroom

Trudy Knowles

Cheryl Medearis

Anne Snell

Follow this and additional works at: https://digitalcommons.unl.edu/podimproveacad

Part of the Higher Education Administration Commons

Knowles, Trudy; Medearis, Cheryl; and Snell, Anne, "Putting Empowerment to Work in the Classroom" (1994). To Improve the Academy. 311.

https://digitalcommons.unl.edu/podimproveacad/311

This Article is brought to you for free and open access by the Professional and Organizational Development Network in Higher Education at DigitalCommons@University of Nebraska - Lincoln. It has been accepted for inclusion in To Improve the Academy by an authorized administrator of DigitalCommons@University of Nebraska - Lincoln. 


\section{Putting Empowerment to Work in the Classroom}

\section{Trudy Knowles}

Westfield State College

\section{Cheryl Medearis}

Sinte Gleska University

\section{Anne Snell}

Burbank High School

At Sinte Gleska University, a tribal college on the Rosebud Sioux Reservation, we are empowering students through our teaching methods and curricular choices. Three areas have been identified as important ingredients in empowering students: validating culture, teaching to learning styles, and utilizing teaching strategies resulting in self-directed learning.

These three elements of empowerment can open up avenues of knowledge that have been previously closed to students on the Rosebud Reservation. As students discover that knowledge is powerful, they begin to learn because they want to.

Change in the fundamental ways we view ourselves as teachers is necessary in order to empower students. In addition, changes in the way we teach, assess, and interact can have a profound impact on our students.

On April 28, 1992, an English class at Crenshaw High School in South Central Los Angeles read the Lanston Hughes' poem "Harlem" (1951). 
What happens to a dream deferred?

Does it dry up

like a raisin in the sun?

Or fester like a sore-

And then run?

Does it stink like rotten meat?

Or crust and sugar over-

like a syrupy sweet?

Maybe it just sags

like a heavy load.

Or does it explode?

The next day, South Central Los Angeles exploded, only hours after a Simi Valley, California, jury found four police officers innocent of the videotaped beating of Rodney King. On that same day in April, the despair that resulted in violence in Los Angeles was being drowned in alcohol on the Rosebud Sioux Reservation in southern South Dakota. Both cultures experienced the anger and anguish of being part of the have-nots of society.

Nowhere are the have-nots more evident than in the educational system, a system that has kept students oppressed. Although some steps in school reform have been taken, on the whole, the have-nots still don't have. Students in South Central Los Angeles and on the Rosebud Reservation still are not empowered in an educational environment that validates their culture, teaches to their learning styles, and employs teaching strategies that result in self-directed learning.

The "Nation at Risk" report in 1983 stated that our education system was mediocre, causing us to be behind other countries in academic achievement (National Commission on Excellence in Education, 1983). To make it better, the Commission proposed more stringent academic requirements, longer school days, a longer school year, and teachers' salaries tied to performance standards. The Com- 
mission's Conclusion, it appears, was that making education harder would make individuals want to learn more.

The commission's suggestions for reform are not only irrelevant to what is happening with the have-nots of education but are also dangerous. Children who don't want to learn will not suddenly want to because it is made harder and takes longer. We run the risk of losing these children to the streets if requirements are made more stringent without a simultaneous commitment to finding ways to nurture and encourage individuals, many of whom need desperately to be set up for success, not failure.

The Commission failed to acknowledge that our educational system has successfully disenfranchised many of its students. The goal of the public school system has been to assimilate and acculturate children into mainstream American life and to perpetuate the status quo (Spring, 1990). The public school system has been especially successful in accomplishing this goal on the Indian reservations. Students were taken away from their families and sent to boarding schools where they were forbidden to use their language, engage in ceremonies, or practice their religion (Rich, 1992; Douville, 1992). Students lost all power and control over their education and over their lives.

\section{Power in the Classroom}

William Glasser (1986) in Control Theory in the Classroom, concluded that schools must make education more satisfying by meeting the internal needs of students-the needs of survival, love, fun, freedom, and power. Glasser asserted that the most critical psychological need that is not being met in public schools all across the country today is the need for power. This lack of power is at the absolute core of school problems.

Sinte Gleska University, on the Rosebud Sioux Indian Reservation, serves a student population that is approximately $75 \%$ Lakota Sioux. At the University, instructors have expressed concern about the number of Lakota students who drop out of classes, fail to pass, have poor attendance, or leave the university altogether. The Lakota Studies Department and the Education Department began to analyze the 
relationship between traditional Lakota views of education and the current teaching strategies in different departments. This analysis revealed three areas that instructors felt could be immediately addressed.

First, we discovered that students on the Rosebud Reservation were being taught in ways that were incompatible with their traditional culture. The Lakota Studies Department saw the loss of Lakota language and Lakota ceremonies as an integral part of the disenfranchisement of the Lakota students. The Lakota Studies Department became interested in ways to empower students through cultural validation.

A second area appeared to be closely related to the first. Instructional methods were often incompatible with student's preferred learning styles. Research indicates that students are more successful when taught to their specific learning style (Dunn, Beaudry \& Klavas, 1989).

The third area of concern related directly to Glasser's conclusions about power and control, that of self-directed learning. When denied the opportunity to learn in culturally compatible ways and when told what to think and how to approach their work, students lost control over their own learning.

\section{Validation of Culture}

The first element that was identified as crucial to empowerment of the students on the Rosebud Reservation was the validation of culture. School has become a place in which many cultures interact to form a microcosm of the world. Students come to school with their own set of prior experiences and assumptions about how this world works. These prior assumptions interplay with the way students understand, interpret, and eventually construct knowledge. Validating the experiences and the individual histories of all students will shift the power back to them. Educational institutions must allow students to use their culture as the basis of their educational process.

Both in South Central Los Angeles and on the Rosebud Sioux Reservation, we have cultures that are the majority in their communities. Despite the majority status of their students, the schools in L.A. and on the Rosebud Reservation are still designed around Eurocentric models. This curriculum model is the primary one in almost all schools 
in this country (Banks \& Banks, 1993). When Lakota students go to school, they often have to leave their culture at home and attempt to learn in a culturally incompatible way.

In traditional Lakota communities, education was largely based on an oral tradition combined with experiential learning. This tradition is in direct conflict with the way schools are being designed today, with a system based on high literacy and written knowledge. In Lakota society, the goal of education is to strengthen the community and the family. Lakota society is strongly cooperative compared to the highly competitive classrooms in most colleges and universities where the emphasis is on individual skills (Douville, 1992). On the Rosebud Reservation we needed to restructure our classes, curriculum and instruction to make education compatible with cultural views.

For the Lakota people, one of the ways to accomplish this task is through increased cooperative learning. At the heart of Lakota society is the concept of the tiospaye, a band of individuals living together, independent of any outside means of control. Each member of the tiospaye was responsible for a specific role or area of expertise, making the survival of the tiospaye dependent upon cooperation among all members. Although the traditional tiospaye was composed of blood relatives, adopted relatives, or relatives by marriage, the concept of the tiospaye as a cooperative system can be transferred to the classroom. Just as the strength of the tiospaye depended upon the strength of each individual member, the strength of the classroom depends upon the success of all students. Cooperation is the essential element for insuring this success.

Learning becomes powerful when it teaches young people to participate in an activity for the common good, when they can ask for help from their peers, and when they can help others. Working cooperatively prepares young people for real life by revealing the life skills necessary to achieve a goal or vision (Slavin, 1983; Johnson, Johnson and Smith, 1991).

\section{Learning Styles}

The second area vital to giving students back control over their own learning is to teach to students' individual learning styles. At Sinte 
we began to look at teachers' instructional methods to determine if the methods used were providing an opportunity for all students to learn according to their strongest modality.

As mentioned before, traditional Lakota education is largely oral and experientially based. Many of our students, when given a learning styles inventory, The Productivity Environmental Preference Survey, PEPS (Dunn, Dunn \& Price, 1992), indicated a preference for auditory presentations combined with tactile/kinesthetic learning experiences. The students do not respond well to strictly lecture. In our education classes we provide instruction utilizing different modalities. Auditory presentations are combined with visual demonstrations. Virtually all concepts are then explored through hands-on activities. Workshops are being developed to help teachers at Sinte offer instruction that will better meet the needs of students with diverse perceptual strengths.

\section{Self-Directed Learning}

The third area identified as important in empowering students is self-directed learning. A decade before the "Nation at Risk" report, Jerome Bruner (1973) stated that "our aim as teachers is to give our students as firm a grasp of a subject as we can, and to make him (her) as autonomous and self-propelled a thinker as we can-one who will go along on his (her) own after formal schooling has ended" (p. 403). Bruner's theory centers the classroom in discovery learning, requiring the students to be active participants and thus empowering students who may feel that they do not have the power to affect their own lives.

A third grader recently told us what he thought was wrong with school. "They never give me any choices," he said. "They tell me what to read, when to talk, how to write, when to eat. They tell me when to wear my coat on the playground. They even tell me where to play." This boy has understood at an early age one of the significant problems in our public school system. This student had already lost power and control over his learning.

Self-directed learning allows students to take part in the formulation of the learning process and play the principle role in it. The students make the important decisions about how they are going to 
find out something. Students involved in the actual activity learn not only content but also learn the process of learning.

In addition, self-directed learning teaches students how to think. When students are allowed to participate in the essential processes of thinking, they move to higher levels of thinking. They recall information, analyze it, evaluate it, and arrive at answers through the synthesis of a multitude of inputs in a holistic and integrated manner. This way of learning is compatible with the Lakota focus on demonstrationbased learning and experiential activities.

The majority of students involved in research at Sinte, however, indicated on the PEPS that they have a high need for structure in the classroom. This need is reflected in their requests to be given direct instructions for assignments. They want to be told exactly what is required of them. We feel that the need for structure is the result of being in a public school system that did not encourage or reward risk taking and that required error-free learning.

Too often students have been told what to think, how to think, and how to let us know what they think. Our university may continue to contribute to this reliance on authority figures through our emphasis on correct answer, multiple choice, fill in the blank tests. When we have strict requirements and strict time lines, we are taking away students' ability to make choices about their own learning. We must begin to look at new ways of delivering classes and alternative ways of assessing knowledge.

Professors at Sinte are beginning to look at portfolio and authentic ways of assessing knowledge. We are attempting to provide more choices in projects and reading assignments. Students are being allowed to do more collaborative projects and to construct their knowledge in ways that make sense to them.

This process is often uncomfortable for professors who have been trained to be the authority figure in a classroom. It is equally uncomfortable for students who have rarely been allowed to become self-sufficient learners. Self-directed learning requires that we trust our students and give them the power that so many professors want to hold on to.

Self-directed learning presents problems at the university level. The obvious problem is convincing the students that they can think for 
themselves. In addition, the bookstore wants our book orders early, before we even meet our students. The Office of Academic Affairs wants our syllabus. Many professors have been teaching the same way for years even with computerized lesson plans. Finally, we have to give that grade.

Enough of excuses. To give students access to power, we must begin to develop ways to give control of learning back to them. We must empower students to think, to direct their own activities, and to be assessed in ways that are comfortable; at the same time, we need to help them stretch their comfort zone.

These three areas of empowerment-validation of culture, teaching to learning styles, and self-directed learning - can open up avenues to knowledge that have been previously closed to students on the Rosebud Reservation. As they discover that knowledge is powerful, they understand, in a profound way, that with knowledge they have the power to get what they want in life. They learn because they want to.

The quest is not over. Sinte Gleska University is only just beginning to develop ways to better meet the needs of its students. But we are continuing to ask significant questions. Are we providing instruction that meets the needs of all perceptual preferences? Are we helping students become independent self-directed learners? Do we have a tolerance for risk taking? Are we providing group learning experiences for those students who learn best through peer interactions? Are our classrooms designed to maximize learning? Are we allowing students to construct their own knowledge out of their own experiences?

The conditions that led to the despair that is being drowned in alcohol can be turned around. What happens to that dream deferred? It dries up. Through empowerment, that dream can be realized.

\section{References}

Banks, J., \& Banks, C. (Eds.) (1993). Multicultural education: Issues and perspectives (2nd ed.). Boston: Allyn \& Bacon.

Bruner, Jerome S. (1973). Beyond the information given. New York: W.W. Norton.

Douville, V. (1992). Unpublished lecture, Sinte Gleska University, Lakota Studies Department, Mission, SD. 
Dunn, R., Dunn, K., \& Price, G. E. (1992). The productivity environmental preference survey (PEPS). Lawrence, KS: Price Systems, Inc.

Dunn, R., Beaudry, J., \& Klavas, A. (1989, March). Survey of research on learning styles. Educational leadership, 50-58.

Glasser, W. (1986). Control theory in the classroom. New York: Harper \& Row.

Hughes, L. (1951). Selected poems. New York: Alfred A. Knopf.

Johnson, D., Johnson, R., \& Smith, K. (1991). Active learning: Cooperation in the college classroom. Edina, MN: Interaction Book Co.

National Commission on Excellence in Education. (1983). A nation at risk. New York: Policy Studies in Education.

Rich, J. (1992). Foundations of education: Perspectives on American education. New York: Macmillan.

Slavin, R. (1980). Cooperative learning. New York: Longman.

Spring, J. (1990). The American School 1642-1990 (2nd ed.). White Plains, New York: Longman. 